\title{
A Diiron Hydrogenase Mimic Featuring a 1,2,3-Triazolylidene
}

\author{
Andrea Mele ${ }^{a}$, Simone Bertinib, Martin Albrecht ${ }^{\mathrm{b}}$, Catherine Elleouet ${ }^{\mathrm{a}}$, François Y. Pétillon ${ }^{\mathrm{a}}$, and \\ Philippe Schollhammer ${ }^{\star a}$
}

\begin{abstract}
A novel complex featuring a mesoionic carbene $\left[\mathrm{Fe}_{2}(\mathrm{CO})_{5}(\operatorname{trz})(\mu-\mathrm{pdt})\right](\mathbf{1})$ (trz $=1$-phenyl-I,3-methyl,4butyl-1,2,3-triazol-5-ylidene), was synthesized and spectroscopically and structurally characterized. The reductive behaviour of this compound in the presence and in the absence of acid $\left(\mathrm{CH}_{3} \mathrm{CO}_{2} \mathrm{H}\right)$ was examined by cyclic voltammetry $(\mathrm{CV})$ that revealed the lack of efficient activity towards proton reduction.
\end{abstract}

Keywords: Bioinspired model $\cdot$ Diiron complex $\cdot$ Hydrogenase $\cdot$ Mesoionic carbene $\cdot$ Proton reduction

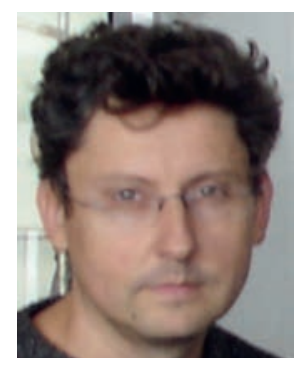

Philippe Schollhammer was appointed as full Professor at the University of Bretagne Occidentale in 2002. He is now the head of the UMR CNRS 6521, CEMCA. His main scientific skills concern the synthesis and the reactivity of organometallic and coordination compounds. His current research interests include activation of small molecules by bioinspired organometallic dinuclear complexes.

\section{Introduction}

The coordination sphere of the active site of $[\mathrm{FeFe}]$ hydrogenase, named $\mathrm{H}$-cluster, is characterized by the presence of three carbonyls and two cyanide ligands coordinated at a dithiolato bridge diiron subsite (Fig. 1a).[1]

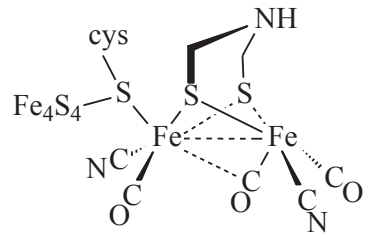

(a)

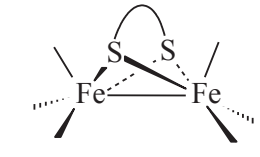

$\left[\mathrm{Fe}_{2}(\mathrm{CO})_{6-\mathrm{x}} \mathrm{L}_{\mathrm{x}}(\mu\right.$-dithiolate $\left.)\right]$ $(\mathrm{x}=0-4)$

(b)
Fig. 1. Schematical view of the H-cluster (a) and mimics (b).

Numerous mimics of the H-cluster have been prepared by replacing in hexacarbonyl diiron precursors $\left[\mathrm{Fe}_{2}(\mathrm{CO})_{6}(\mu-\right.$ dithiolate)] carbonyl groups with various sets of terminal ligands (Fig. 1b). ${ }^{[2]}$ Very close structural cyanide models $\left[\mathrm{Fe}_{2}(\mathrm{CO})_{6-\mathrm{x}}(\mathrm{CN})_{\mathrm{x}}\right.$ ( $\mu$-dithiolate $)]^{\mathrm{x}-}(\mathrm{x}=1,2)$ of the diiron subsite were obtained, but despite their strong resemblance they did not display high activity towards $\mathrm{H}^{+} / \mathrm{H}_{2}$ conversion. ${ }^{[3]} \mathrm{N}$-heterocyclic carbenes (NHC) are considered as good candidates to replace cyanide ligands because of their well-defined preparation, good $\sigma$-donor properties and the possibility to tune their steric bulkiness. ${ }^{[4,5]}$ Despite the wide use of such carbenes as ligands in catalysis by transition metal complexes, ${ }^{[6]}$ relatively few examples of diiron compounds with $\mathrm{NHC}$ ligands, as models of the H-cluster, have been reported in comparison to the number of phosphine-based diiron model systems. ${ }^{[7]}$ The electrocatalytic activity of such NHC-diiron species towards proton reduction into $\mathrm{H}_{2}$ has been little explored. This reduction process arises through the formation of a di-anionic intermediate that may be protonated into a hydride species. A second protonation would release $\mathrm{H}_{2}$. The possible role of the $N$-heterocyclic carbene as a non-innocent redox ligand in the initial two-electron reduction has been suggested. [7b]

It is worth noting that until now, monosubstituted and disubstituted NHC diiron complexes of general formula $\left[\mathrm{Fe}_{2}(\mathrm{CO})_{6}\right.$ $\left.(\mathrm{NHC})_{\mathrm{x}}(\mu-\mathrm{pdt})\right](\mathrm{x}=1,2)$ are mainly based on the classical NHC ligand based on an imidazole ring (Fig. 2a). To the best of our knowledge no example of diiron systems with nonclassical NHC ligands have been reported. For this reason the combination of a bioinspired diiron core with different types of carbenes like mesoionic carbenes (MICs) (Fig. 2b), since they have some unique properties among all other NHC ligands,,${ }^{[4,5,8]}$ may afford original insight into the chemistry of NHC-diiron complexes. Mesoionic carbenes are stronger $\sigma$-donors than imidazol-2-ylidenes by reason of the absence of canonical resonance structure. This characteristic may strongly enhance the basicity of the diiron core allowing easier protonation.<smiles>[R]C1=C([R])N([R])CN1[R]</smiles>

(a)

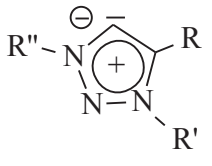

(b)
Fig. 2. NHC ligands based on an imidazole ring (a) and triazole-derived mesoionic carbenes (b).

The goal of the work presented herein was to design original diiron complexes featuring triazole-derived MIC ligands and to examine their electrocatalytic activity towards proton reduction in order to verify that their stronger donor ability favours effi- 
cient $\mathrm{H}_{2}$ generation and to determine whether these ligands are partially reduced during the process. Preliminary results concerning the preparation, characterization and the redox behaviour of a novel diiron hydrogenase mimic featuring a 1,2,3-triazolylidene are presented.

\section{Results and Discussion}

The product $\left[\mathrm{Fe}_{2}(\mathrm{CO})_{5}(\mathrm{trz})(\mu-\mathrm{pdt})\right](\mathbf{1}, \operatorname{trz}=1$-phenyl-, $3-$ methyl,4-butyl-1,2,3-triazol-5-ylidene) was prepared by reacting the hexacarbonyl diiron starting product $\left[\mathrm{Fe}_{2}(\mathrm{CO})_{6}(\mu-\mathrm{pdt})\right]$ (pdt $=$ propanedithiolate $)$ with a triazolium salt in the presence of potassium tert-butoxide (Fig. 3). 1 was characterized by IR, NMR $\left({ }^{1} \mathrm{H},{ }^{13} \mathrm{C}\right)$ spectroscopies, elemental analysis and X-ray diffraction.

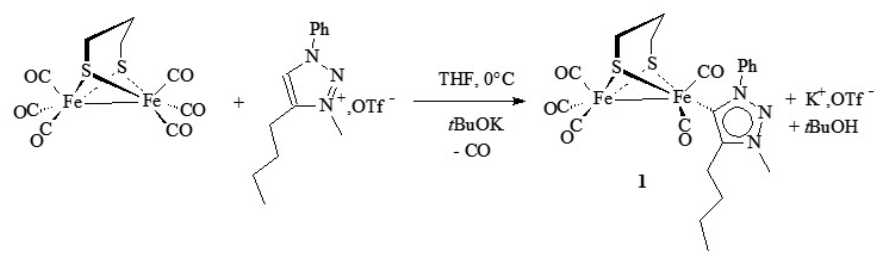

Fig. 3. Synthesis of $\left[\mathrm{Fe}_{2}(\mathrm{CO})_{5}(\mathrm{trz})(\mu-\mathrm{pdt})\right]$ (1).

The clean substitution of one carbonyl group by the triazolylidene ligand in $\left[\mathrm{Fe}_{2}(\mathrm{CO})_{6}(\mu-\mathrm{pdt})\right]$ was followed by IR monitoring. The disappearance of the bands of the starting product was observed concomitantly with the appearance of a new set of $\mathrm{CO}$ bands at lower wavenumbers. The IR spectrum in $\mathrm{CH}_{2} \mathrm{Cl}_{2}$ of $\mathbf{1}$ displays a typical pattern in the $\mathrm{CO}$ region, expected for a monosubstituted complex with a $\left\{\mathrm{Fe}_{2}(\mathrm{CO})_{5} \mathrm{~L}\right]$ core (Table 1). Considering average values of carbonyl wavenumbers (Table 1) may allow interesting trends to be identified. A shift of $60 \mathrm{~cm}^{-1}$ is observed for the $v(\mathrm{CO})$ bands of $\mathbf{1}$ compared to those of the hexacarbonyl diiron precursor, which is close to that observed for the cyanide complex $\left[\mathrm{Fe}_{2}(\mathrm{CO})_{5}(\mathrm{CN})(\mu \text {-pdt })\right]^{-}$. This shift accords with the replacement of one $\mathrm{CO}$ by a better donor ligand such as trz and confirms the strong donor strength of this latter ligand. Furthermore, as expected, IR spectroscopy suggests that this 1,2,3-triazole carbene is a better donor than imidazole carbenes $\left(\Delta v(\mathrm{CO})=9\right.$ (IMet)-15 (IMes) $\left.\mathrm{cm}^{-1}\right)$.

Complex 1 was crystallized from slow evaporation of a solution of hexane/dichloromethane $(1: 1)$ at $-30^{\circ} \mathrm{C}$ and its structure

Table 1. IR values in the CO region of some analogous complexes (IMes = 1,3-dimesitylimidazol-2-ylidene , IMet = 1,3-dimethylimidazol-2-ylidene, (a) in THF, (b) in $\mathrm{CH} 3 \mathrm{CN}$, (c) in $\mathrm{CH}_{2} \mathrm{Cl}_{2}$

\begin{tabular}{|c|c|c|}
\hline Compound & $v \mathbf{C O} / \mathbf{~ c m}^{-\mathbf{1}}$ & $\begin{array}{c}\text { Average } \\
v \mathbf{C O} / \mathbf{~ c m}^{-\mathbf{1}}\end{array}$ \\
\hline$\left[\mathrm{Fe}_{2}(\mathrm{CO})_{6}(\mu-\mathrm{pdt})\right]^{[3 \mathrm{c}]}$ & $\begin{array}{c}2072,2033,1999, \\
1990^{\mathrm{c}}\end{array}$ & 2024 \\
\hline$\left[\mathrm{Fe}_{2}(\mathrm{CO})_{5}(\mathrm{CN})(\mu-\mathrm{pdt})\right]^{-[3 \mathrm{c}]}$ & $\begin{array}{c}2027, \\
1977,1944,\end{array}$ & 1967 \\
\hline$\left[\mathrm{Fe}_{2}(\mathrm{CO})_{5}(\mathrm{IMes})(\mu-\mathrm{pdt})\right]^{[7 \mathrm{~b}]}$ & $\begin{array}{c}2035,2027,1969, \\
1947,1916^{\mathrm{a}}\end{array}$ & 1979 \\
\hline$\left[\mathrm{Fe}_{2}(\mathrm{CO})_{5}(\mathrm{IMet})(\mu-\mathrm{pdt})\right]^{[7 \mathrm{a}]}$ & $\begin{array}{c}2036,1971, \\
1912^{\mathrm{b}}\end{array}$ & 1973 \\
\hline$\left[\mathrm{Fe}_{2}(\mathrm{CO})_{5}(\mathrm{trz})(\mu-\mathrm{pdt})\right](\mathbf{1})$ & $2028,1969,1950$, & 1964 \\
\hline
\end{tabular}

was determined by an X-ray diffraction analysis (Fig. 4 and Table 2 in experimental section).

The trz ligand lies in basal position in $\mathbf{1}$, in contrast to other analogous complexes in which the imidazole-derived carbene is in apical position. ${ }^{[7 a, b, h]}$ This difference may be related to the more important steric bulkiness of the $n$-butyl moiety hampering the $\mathrm{CO}$ substitution in the apical position. The Fe-C(trz) distance (1.9839(19) $\AA$ ) compares well with that observed for other NHC-monosubstituted diiron complexes $\left[\mathrm{Fe}_{2}(\mathrm{CO})_{5} \mathrm{~L}(\mu\right.$-pdt $\left.)\right] .{ }^{[3 \mathrm{a}]}$ The $\mathrm{Fe}-\mathrm{Fe}$ length $(2.5635(4) \AA)$ is in the range of that expected for a single $\mathrm{Fe}-\mathrm{Fe}$ bond in $\mathrm{Fe}(\mathrm{I}) \mathrm{Fe}(\mathrm{I})$ models of the H-cluster. ${ }^{[2]}$ The two iron atoms have approximatively square pyramidal coordination geometry. The overall geometry of $\mathbf{1}$ is unexceptional. Distances and angles will not be further commented on.

The complex was characterized by ${ }^{1} \mathrm{H}$ and ${ }^{13} \mathrm{C}\left\{{ }^{1} \mathrm{H}\right\}$ NMR spectroscopies in $\mathrm{CD}_{2} \mathrm{Cl}_{2}$. The ${ }^{1} \mathrm{H} \mathrm{NMR}$ spectrum displays in the aromatic area $(\sim 7.5 \mathrm{ppm})$ signals expected for the phenyl ring. A sharp singlet is detected at $4.04 \mathrm{ppm}$, corresponding to the $\mathrm{N}-\mathrm{CH}_{3}$ group. Signals of the $n$-butyl and propanedithiolate are typically observed between 1 and $2 \mathrm{ppm}$. In the ${ }^{13} \mathrm{C}\left\{{ }^{1} \mathrm{H}\right\}$ NMR spectrum of $1 \mathrm{in} \mathrm{CD}_{2} \mathrm{Cl}_{2}$ (see experimental section), two signals at $216.61 \mathrm{ppm}$ and $211.77 \mathrm{ppm}$ are assigned to the five $\mathrm{CO}$ groups of $\left\{\mathrm{Fe}(\mathrm{CO})_{3}\right\}$ and $\left\{\mathrm{Fe}(\mathrm{CO})_{2}\right\}$ moieties of the complex. The resonance at 171.16 ppm is assigned to the carbenic carbon of the trz ligand bonded to one iron atom and the signal at $148.10 \mathrm{ppm}$ is attributed to the second carbon of the 1,2,3-triazole ring. The other signals for phenyl, $n$-butyl, propanedithiolate and N-Me groups (see experimental section) are in accordance with the molecular structure of $\mathbf{1}$.

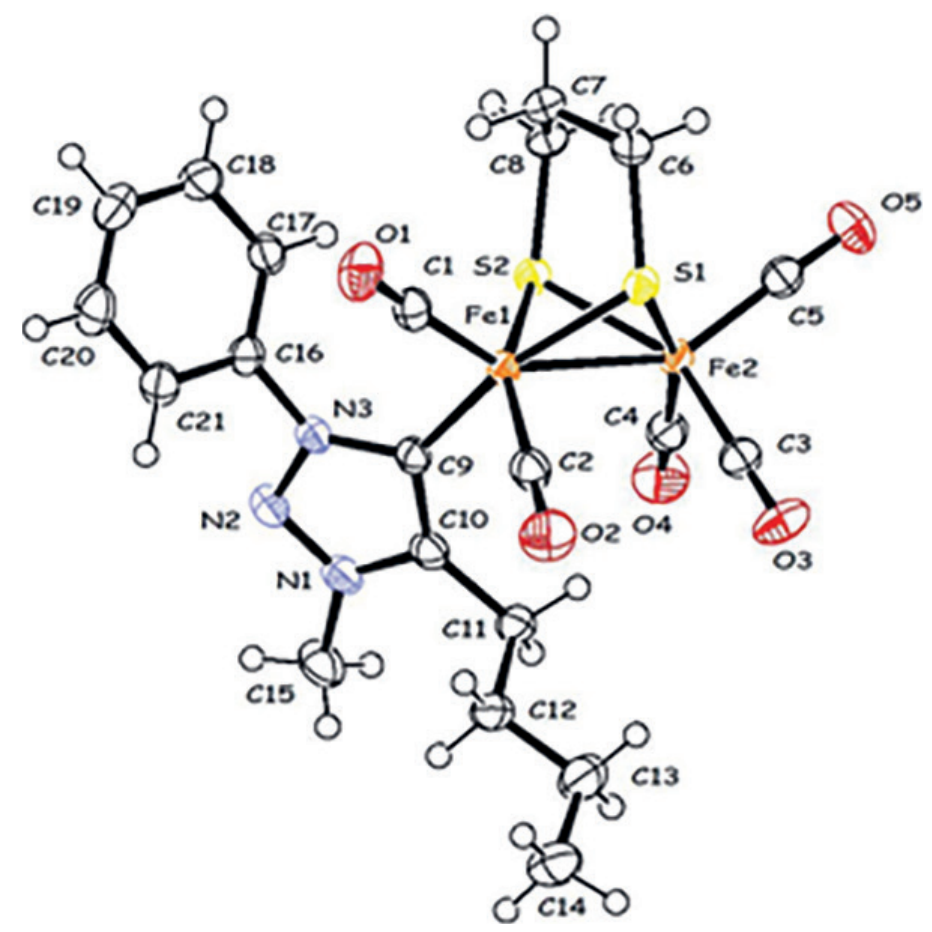

Fig. 4. Ortep view (ellipsoids at $30 \%$ of probability level) of 1 . Selected distances $(\AA \AA)$ and angles (deg): C9-Fe1, 1.9839(19); Fe1-Fe2, 2.5635(4); $\mathrm{S} 1-\mathrm{Fe} 1,2.2414(5) ; \mathrm{S} 1-\mathrm{Fe} 2,2.2631(5) ; \mathrm{S} 2-\mathrm{Fe} 2,2.2634(5) ; \mathrm{S} 2-\mathrm{Fe} 1$, 2.2668(5); C9-N3, 1.386(2); C9-C10, 1.400(3); C15-N1, 1.468(2); N1N2, 1.313(2); N2-N3, 1.342(2); C10-N1, 1.362(3); C16-N3, 1.439(2); C1-O1, 1.148(2); C1-Fe1, 1.769(2); C2-O2, 1.154(2); C2-Fe1, 1.760(2); C3-O3, 1.143(2); C3-Fe2, 1.785(2); C4-O4, 1.142(3); C4-Fe2, 1.788(2); C5-O5,1.144(2); C5-Fe2, 1.797(2); Fe1-S1-Fe2, 69.372(16); Fe2-S2-Fe1, 68.926(16); C5-Fe2-Fe1, 145.85(7); C1-Fe1-Fe2, 148.85(7); C9-Fe1-Fe2, 107.60(6); C2-Fe1-Fe2, 99.10(7); C3-Fe2-Fe1, 98.36(7); C4-Fe2-Fe1, 107.80(7). 
Cyclic voltammograms at $0.2 \mathrm{~V} \mathrm{~s}^{-1}$ in $\mathrm{CH}_{2} \mathrm{Cl}_{2}-\left[\mathrm{NBu}_{4}\right]\left[\mathrm{PF}_{6}\right]$ $(0.2 \mathrm{M})$ show that 1 has an irreversible reduction at $E_{\mathrm{p}}{ }^{\mathrm{c}}=-2.29 \mathrm{~V}$ vs $\left(\mathrm{Fc}^{+} / \mathrm{Fc}\right)$ and a one-electron quasi-reversible oxidation at $E_{1 / 2}$ $=0.021 \mathrm{~V}$ vs $\left(\mathrm{Fc}^{+/} \mathrm{Fc}\right)$ with a ratio $\left(\mathrm{i}_{\mathrm{p}}^{\mathrm{c}, \mathrm{xx} 1} / \mathrm{i}_{\mathrm{p}}^{\mathrm{a}, \mathrm{ox} 1}\right)$ of approx. 1 (Fig. 5). Compound 1 displays similar reduction behaviour to that observed for analogous compounds bearing NHC ligands. ${ }^{[7, b, h]}$

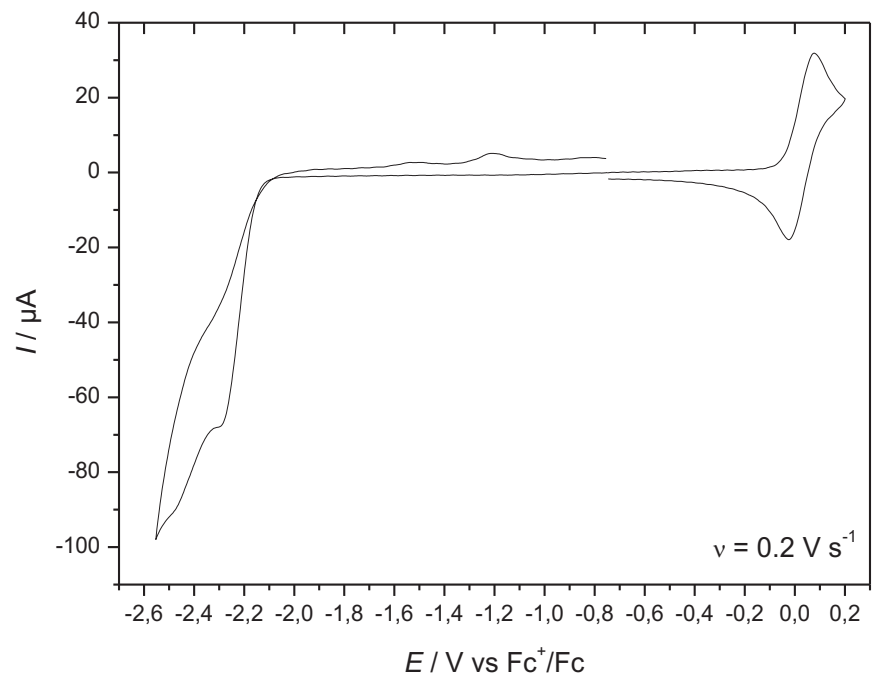

Fig. 5. Cyclic voltammograms of $\mathbf{1}(1.2 \mathrm{mM})$ in $\mathrm{CH}_{2} \mathrm{Cl}_{2}-\left[\mathrm{NBu}_{4}\right]\left[\mathrm{PF}_{6}\right](0.2$ $\mathrm{M})$, under $\mathrm{Ar}$ at $0.2 \mathrm{~V} \mathrm{~s}^{-1}$.

The variation of the reduction peak current as a function of the square root of the scan rate $(v)$ is linear, indicating that the reductive process is controlled by diffusion at slow scan rates. At $0.2 \mathrm{~V} \mathrm{~s}^{-1}$ the ratio between the cathodic peak current $\left(i_{p}^{c}\right)$ of the reduction at $E_{p}=-2.29 \mathrm{~V}$ vs $\left(\mathrm{Fc}^{+} / \mathrm{Fc}\right)$ and the anodic current peak $\left(\mathrm{i}_{\mathrm{p}}{ }^{a}\right)$ of the one-electron oxidation at $E_{1 / 2}=0.021 \mathrm{~V}$ vs $\left(\mathrm{Fc}^{+/} \mathrm{Fc}\right)$ is $c a .2$ and suggests that two electrons are involved in the reduction process. The current function $\left(\mathrm{i}_{\mathrm{p}}{ }^{\mathrm{c}} \mathrm{v}^{-1 / 2}\right)$ as a function of $v$ was plotted (Fig. 6) and the deviation from linearity observed at the slowest scan rates suggests that an ECE mechanism is operative at these scan rates. Two-electron reduction processes have been already reported for other diiron complexes featuring NHC ligands. The transfer of one electron to the diiron core and that of the second electron to the NHC ligand were proposed to rationalize this behaviour. $[7 \mathrm{~b}, \mathrm{~h}]$

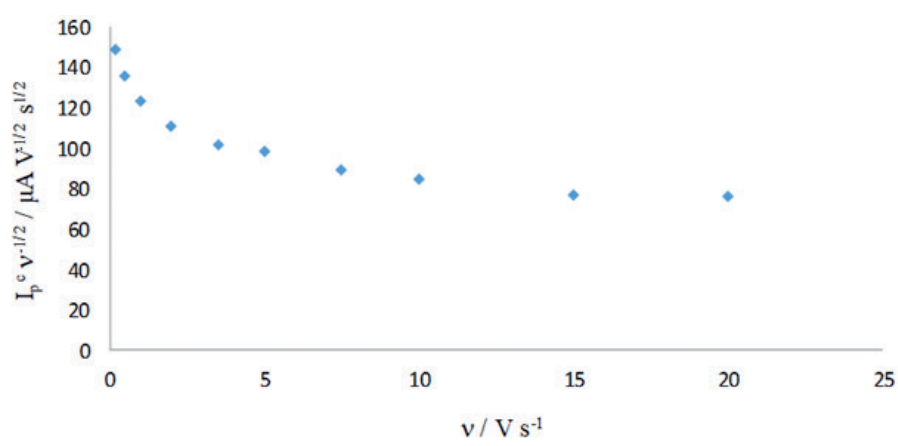

Fig. 6. Scan rate dependence of the current function for the reduction of $1(0.2 \mathrm{M})$ under $\mathrm{Ar}$ in $\mathrm{CH}_{2} \mathrm{Cl}_{2}-\left[\mathrm{NBu}_{4}\right]\left[\mathrm{PF}_{6}\right](0.2 \mathrm{M})$.

The electrochemical study of $\mathbf{1}$ in the presence of acetic acid was carried out in $\mathrm{CH}_{2} \mathrm{Cl}_{2}$, since complexes bearing $\mathrm{NHC}$ ligands were reported to react over time with coordinating solvents, such as $\mathrm{CH}_{3} \mathrm{CN}$, leading to a mixture of products, which complicates the interpretation of experimental data. ${ }^{[7 b]}$ Upon addition of acetic acid, a slight enhancement of the peak current related to the quantity of acetic acid added is observed (Fig. 7a).

The observed redox behaviour in the presence of proton source is comparable with those of other similar diiron complexes bearing NHC ligands for which an electrocatalytic reduction of protons was proposed. ${ }^{[7 b, h]}$ For example, the closely related electrochemical behaviour of the complex $\left[\mathrm{Fe}_{2}(\mathrm{CO})_{5}(\mathrm{IMes})(\mu\right.$-pdt $\left.)\right]$ in the presence of a proton source has been reported previously. ${ }^{[7 \mathrm{~h}]}$ However, the small enhancement of the current suggests that the catalytic activity is low, if any catalytic process could be actually considered, and it can be readily deduced that replacing the IMes group with the trz ligand leads to comparable results, indicating that there is apparently no significant differences between the two families of mimicking models. From a mechanistic point of view, the CVs suggest that there is no protonation prior to the reduction of such complexes. Indeed, an initial protonation of $\mathbf{1}$ would be detected by the reduction of the protonated species at a less negative potential than that of $\mathbf{1}$, which is not observed. Moreover, there is no significant decrease of the oxidation signal upon addition of increasing amounts of acid (Fig. 7b), which indicates that the complex has not reacted in solution. No overpotential was calculated for this process because of the absence of available pKa values for $\mathrm{CH}_{3} \mathrm{COOH}$ in $\mathrm{CH}_{2} \mathrm{Cl}_{2}$ in literature and the very low catalytic efficiency, if any. Furthermore, the superposition of the $\mathrm{CV}$ of $\mathbf{1}$ in the presence of the highest quantity of acid added ( $5 \mathrm{mM} \mathrm{CH}_{3} \mathrm{CO}_{2} \mathrm{H}$ in $\mathrm{CH}_{2} \mathrm{Cl}_{2}$, red curve) and that of a solution of $\mathrm{CH}_{3} \mathrm{CO}_{2} \mathrm{H}$ in the absence of the iron complex (black curve) (Fig. 8) shows that the reduction of the $\mathrm{CH}_{3} \mathrm{CO}_{2} \mathrm{H}$ arises at -2.3 $\mathrm{V}$ vs $\left(\mathrm{Fc}^{+} / \mathrm{Fc}\right)$ and its contribution to the current intensity is not negligible. Therefore, no catalytic efficiency was determined.

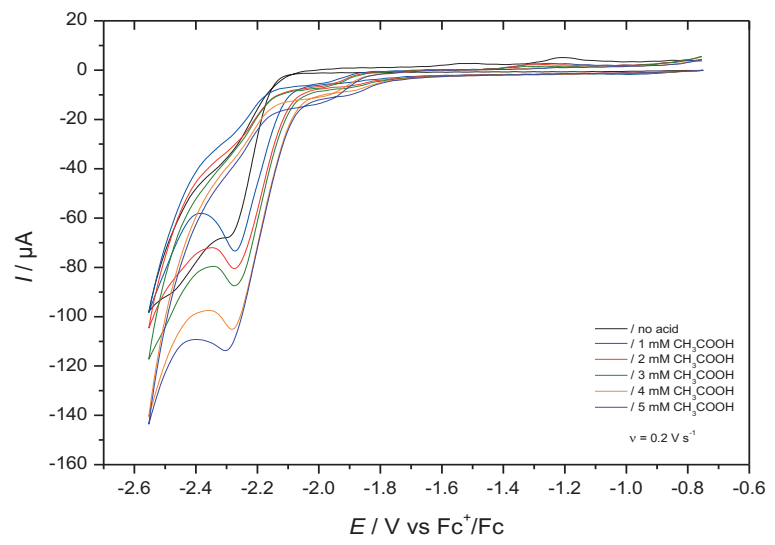

(a)

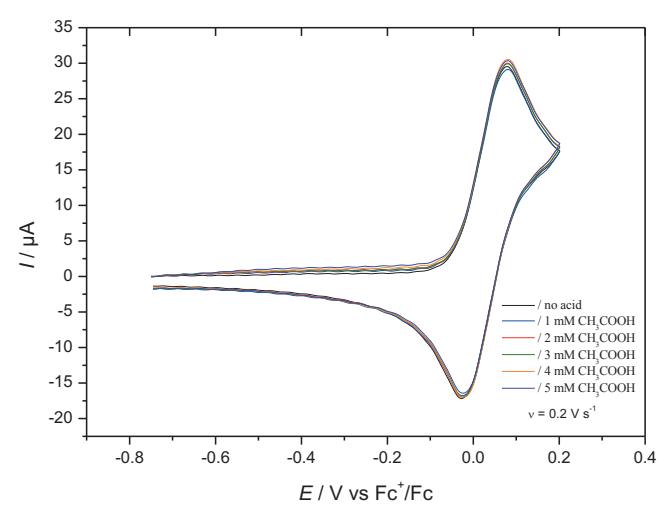

(b)

Fig. 7. Complex $1(1 \mathrm{mM})$ in the presence of $\mathrm{CH}_{3} \mathrm{COOH}(1-5 \mathrm{mM})$ in $\mathrm{CH}_{2} \mathrm{Cl}_{2}-\left[\mathrm{NBu}_{4}\right]\left[\mathrm{PF}_{6}\right](0.2 \mathrm{M})$ under Ar; (a) reduction and (b) oxidation scans. 


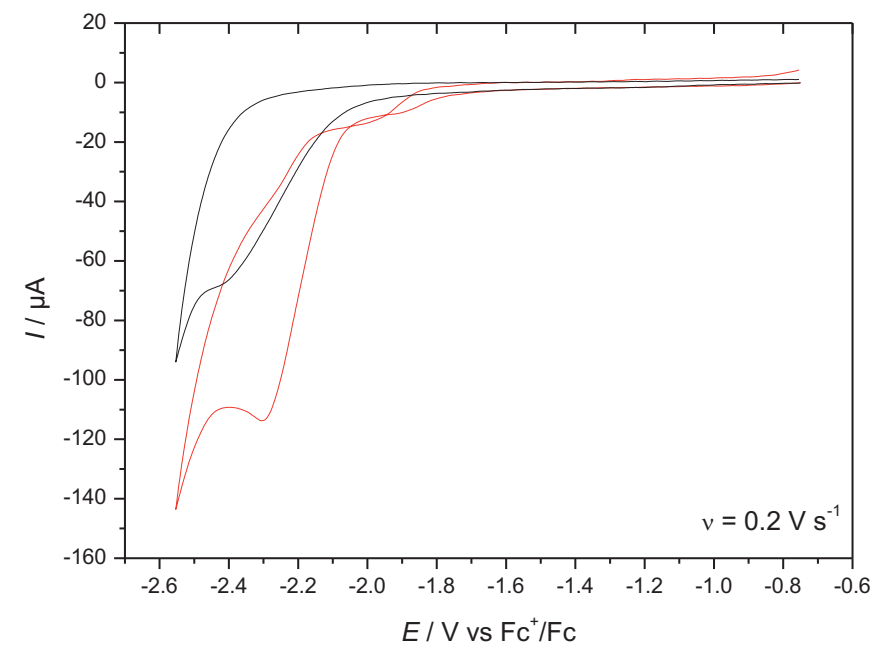

Fig. 8. Superposition of the $\mathrm{CV}$ of 1 in the presence of $\mathrm{CH}_{3} \mathrm{CO}_{2} \mathrm{H}(5 \mathrm{mM})$ (red curve) and that of a solution of $\mathrm{CH}_{3} \mathrm{CO}_{2} \mathrm{H}(5 \mathrm{mM})$ (black curve) in $\mathrm{CH}_{2} \mathrm{Cl}_{2}-\left[\mathrm{NBu}_{4}\right]\left[\mathrm{PF}_{6}\right](0.2 \mathrm{M})$.

\section{Conclusions}

The synthesis and the study of a novel complex $\left[\mathrm{Fe}_{2}(\mathrm{CO})_{5}(\mathrm{trz})\right.$ $(\mu$-pdt)] (1) featuring a $N$-heterocyclic carbene ligand based on triazole is reported. Its redox behaviour in reduction was examined by cyclic voltammetry, which suggests the absence of efficient catalytic proton reduction, similar to other NHC monosubstituted complexes bearing imidazole-derived carbenes. Theoretical calculations are under investigation to determine if the triazolylidene acts as an innocent or non-innocent redox ligand. The trz group enhances the electron density of the diiron core but it may not have any effect on the nature and stability of reduced species nor any particular influence in the hydrogen evolution reaction. The extension of this series of complexes, through the replacement of substituents on the triazolyl ligand, is now considered in order to enhance the activity of this kind of complexes towards proton reduction and to establish or improve metal-ligand communication by using electron-donating or electron-withdrawing groups, respectively.

\section{Experimental}

All the experiments were carried out under an inert atmosphere, using Schlenk techniques for the syntheses. Solvents were deoxygenated and dried according to standard procedures. The iron precursor $\left[\mathrm{Fe}_{2}(\mathrm{CO})_{6}(\mu \text {-pdt })\right]^{[3 \mathrm{c}, 9]}$ and 1-phenyl-3-methyl-4-butyl1,2,3-triazolium triflate ${ }^{[10]}$ were prepared according to literature procedures. All other reagents were commercially available and used as purchased. The NMR spectra $\left({ }^{1} \mathrm{H}\right.$ and $\left.{ }^{13} \mathrm{C}\right)$ were recorded with a Bruker DRX500 spectrometer of the 'Service général des plateformes, Université de Bretagne Occidentale, Brest'. The infrared spectra were recorded on a FT IR VERTEX 70 Bruker spectrometer. Chemical analyses were made by the 'Service de Microanalyse I.C.S.N.', Gif sur Yvette (France). Electrochemical measurements were conducted using a PG-STAT $128 \mathrm{~N}$ Autolab or a $\mu$-autolab (type III) electrochemical analyser driven by GPES software. All the electrochemical studies were carried out in a conventional three-electrode cell under an inert atmosphere of either $\mathrm{N}_{2}$ or Ar. The preparation and the purification of the supporting electrolyte $\left[\mathrm{NBu}_{4}\right]\left[\mathrm{PF}_{6}\right]$ have been described previously. ${ }^{[11]}$ The working electrode was a vitreous carbon disk of $0.3 \mathrm{~cm}$ in diameter, polished with alumina prior to use. A platinum wire was used as counter electrode. The reference electrode was an $\mathrm{Ag}_{\mathrm{Ag}} \mathrm{Ag}^{+}$ electrode, however, all the potentials (text, tables, and figures) are quoted against the $\left(\mathrm{Fc}^{+} / \mathrm{Fc}\right)$ couple; ferrocene was added as an internal standard at the end of the experiments. Crystal data for compound 1 were collected on a Oxford Diffraction X-Calibur-2
CCD diffractometer, equipped with a jet cooler device and graphite-monochromated Mo-K $\alpha$ radiation $(\lambda=0.71073 \AA)$. The structure was solved and refined by standard procedures (Table 2) Deposition number CCDC 1999260 contains the supplementary data for 1. [12]

Table 2. Crystallographic data and refinement parameters of $\mathbf{1}$.

ra

Empirical formula
Formula weight
Temperature $\left({ }^{\circ} \mathrm{K}\right)$
Wavelength $(\AA)$
Crystal system, space group
Unit cell dimensions

$\mathrm{C}_{21} \mathrm{H}_{23} \mathrm{Fe}_{2} \mathrm{~N}_{3} \mathrm{O}_{5} \mathrm{~S}_{2}$

573.24

$170(2)$

0.71073

Monoclinic, P 1 21/c1

a $(\AA)$ a $(\AA)$

9.1865(2)

b ( $\mathrm{A})$

14.7206(3)

c $(\AA)$

18.0972(4)

$\beta\left(^{\circ}\right)$

94.263(2)

Volume $\left(\AA^{3}\right)$

2440.53(9) $\AA^{3}$

Z

4

Calculated density $\left(\mathrm{Mg} / \mathrm{m}^{3}\right)$

1.560

Absorption coefficient (mm-1)

1.397

$\mathrm{F}(000)$

1176

Crystal colour

Red

Crystal size (mm)

$0.42 \times 0.37 \times 0.22$

Theta range for data collection $\left(^{\circ}\right)$

Limiting indices

3.35 to 26.37

Reflections collected / unique

$-7 \leq \mathrm{h} \leq 11,-18 \leq \mathrm{k} \leq 18$, $-22 \leq 1 \leq 22$

$15665 / 4982$

$[\mathrm{R}(\mathrm{int})=0.0426]$

Completeness to theta $=26.37(\%) \quad 99.7$

Absorption correction

Semi-empirical from equivalents

Max. and min. transmission

0.7487 and 0.5916

Refinement method

Full-matrix least-squares on F2

Data / restraints / parameters

4982 / 0 / 300

Goodness-of-fit on $\mathrm{F}^{2}$

1.085

Final $R$ indices [I $>2 \sigma(I)]$

$\mathrm{R}_{1}=0.0295, \mathrm{wR}_{2}=0.0743$

$\mathrm{R}$ indices (all data)

Largest diff. peak and hole (e. $\left.\AA^{-3}\right)$

$\mathrm{R}_{1}=0.0343, \mathrm{wR}_{2}=0.0787$

0.410 and -0.346

\subsection{Synthesis of $\left[\mathrm{Fe}_{2}(\mathrm{CO})_{5}(\mathrm{trz})(\mu-p d t)\right](1)$}

A solution of $\left[\mathrm{Fe}_{2}(\mathrm{CO})_{6}(\mu\right.$-pdt $\left.)\right](200 \mathrm{mg}, 0.518 \mathrm{mmol})$ with an excess of 1-phenyl-3-methyl-4-butyl-1,2,3-triazolium triflate (380 mg, $1.04 \mathrm{mmol}$ ) was prepared in degassed anhydrous THF $(25 \mathrm{~mL}) .146 \mathrm{mg}$ of potassium tert-butoxide $(1.30 \mathrm{mmol})$ were 
added at $0{ }^{\circ} \mathrm{C}$ under vigorous stirring and the mixture was stirred for 30 minutes. The solvent was evaporated under reduced pressure to dryness and then $10 \mathrm{~mL}$ of $\mathrm{CH}_{2} \mathrm{Cl}_{2}$ were added. The resulting red suspension was filtered over Celite and evaporated to dryness to yield 1 as a red powder (184 mg, 62\%). Crystallization by slow diffusion at $-35{ }^{\circ} \mathrm{C}$ (hexane/dichloromethane 1:1) afforded single crystals suitable for X-ray diffraction analysis.

IR: $\left(\mathrm{CH}_{2} \mathrm{Cl}_{2}, \mathrm{~cm}^{-1}\right):=\mathrm{v}(\mathrm{CO})$ 2028(s), 1969(s), 1950(s), 1907(m). ${ }^{1} \mathrm{H}$ NMR: $\left(\mathrm{CD}_{2} \mathrm{Cl}_{2}, 500 \mathrm{MHz}, \mathrm{ppm}\right): \delta 7.63$ (C17, $\mathrm{C} 21-H$, br s, 2H), 7.57 (C18, C19, C20-H, m, 3H), 4.04 (C15, $\mathrm{s}, 3 \mathrm{H}), 1.94(\mathrm{~m}, 2 \mathrm{H})+1.79(\mathrm{~m}, 2 \mathrm{H})+1.68(\mathrm{~m}, 3 \mathrm{H})+1.55(\mathrm{~m}$, $5 \mathrm{H})+1.01\left(\mathrm{t}, J_{\mathrm{HH}}=7.5 \mathrm{~Hz}, 3 \mathrm{H}\right)\left(\mathrm{S}\left(\mathrm{CH}_{2}\right)_{3} \mathrm{~S}+n\right.$-butyl $) .{ }^{13} \mathrm{C}\left\{{ }^{1} \mathrm{H}\right\}$ NMR: ( $\left.\mathrm{CD}_{2} \mathrm{Cl}_{2}, 125 \mathrm{MHz}, \mathrm{ppm}\right): \delta 216.61$ (C3, C4, C5), 211.17 (C1, C2), 171.17 (C9), 148.10 (C10), 140.40, 129.98, 128.61, $129.48\left(\mathrm{C}_{6} \mathrm{H}_{5}\right), 36.31$ (C15), 30.83, 29.92, 26.52, 23.06, 13.42 $\left(\mathrm{S}\left(\mathrm{CH}_{2}\right)_{3} \mathrm{~S}+n\right.$-butyl) (numbering of carbon atoms corresponds to that of the ORTEP diagram). Elemental analysis calculated for $\mathrm{C}_{17} \mathrm{H}_{14} \mathrm{Fe}_{2} \mathrm{~N}_{3} \mathrm{O}_{5} \mathrm{~S}_{2}: 44.00 \% \mathrm{C}, 4.04 \% \mathrm{H}, 7.33 \% \mathrm{~N}$; found: $43.86 \%$ $\mathrm{C}, 3.98 \% \mathrm{H}, 7.27 \% \mathrm{~N}$.

\section{Acknowledgements}

This work was supported by the European Union Marie SklodowskaCurie Initial Training Network NoNoMeCat project (675020-H2020MSCA-ITN-2015). CNRS (Centre National de la Recherche Scientifique), the Université de Bretagne Occidentale, are also acknowledged for financial support. We are grateful to Dr F. Michaud for the crystallographic measurements of $\mathbf{1}$ and to the 'Service général des plateformes, Brest' for NMR measurements on the Brucker DRX 500 spectrometer.

Received: April 23, 2020

[1] a) J. W. Peters, W. N. Lanzilotta, B. J. Lemon, L. C. Seefeldt, Science 1998, 282, 1853; b) Y. Nicolet, C. Piras, P. Legrand, C. E. Hatchikian, J. C. Fontecilla-Camps, Structure 1999, 7, 13.

[2] a) C. Tard, C. J. Pickett, Chem. Rev. 2009, 109, 2245; b) U.-P. Apfel, F. Y. Pétillon, P. Schollhammer, J. Talarmin, W. Weigand, '[FeFe] Hydrogenase Models: An Overview', in 'Bioinspired Catalysis: Metal-Sulfur Clusters', Ed. W. Weigand, P. Schollhammer Wiley-VCH, 2014; c) D. Schilter, J. M. Camara, M. T. Huynh, S. Hammes-Schiffer, T. B. Rauchfuss, Chem. Rev. 2016, 116, 8693; d) C. Elleouet, F. Y. Pétillon, P. Schollhammer, '[FeFe]hydrogenases Models', in 'Advances in bioorganometallic chemistry', Ed. T. Hirao, T. Moriuchi, Elsevier, 2019; e) T. R. Simmons, G. Berggren, M. Bacchi, M. Fontecave, V. Artero, Coord. Chem. Rev. 2014, 270-271, 127; f) J.-F. Capon, F. Gloaguen, F. Y. Pétillon, P. Schollhammer, J. Talarmin, Eur J. Inorg. Chem. 2008, 4671.

[3] a) E. J. Lyon, I. P. Georgakaki, J. H. Reibenspies, M. Y. Darensbourg, J. Am. Chem. Soc. 2001, 123, 3268; b) A. Le Cloirec, S. C. Davies, D.J. Evans, D. L. Hughes, C. J. Pickett, S. P. Best, S. Borg, Chem. Commun. 1999, 2285 ; c) E. J. Lyon, I.P. Georgakaki, J.H. Reibenspies, M.Y. Darensbourg,
Angew. Chem. Int. Ed. 1999, 38, 3178; d) M. Schmidt, S. M. Contakes, T. B. Rauchfuss, J. Am Chem. Soc. 1999, 121, 9736; e) J. D. Lawrence, H. Li, T. B. Rauchfuss, M. Bénard, M.-M. Rohmer, Angew. Chem. Int. Ed. 2001, 40, 1768; f) M. Razavet, S. C. Davies, D. L. Hughes, C. J. Pickett, Chem. Commun. 2001, 847; g) F. Gloaguen, J. D. Lawrence, M. Schmidt, S. R. Wilson, T. B. Rauchfuss, J. Am. Chem. Soc. 2001, 123, 12518; h) S. J. George, Z. Cui, M. Razavet, C. J. Pickett, Chem. Eur. J. 2002, 8, 4037; i) H. Li, T. B. Rauchfuss, J. Am Chem. Soc. 2002, 124, 726.

[4] H. V. Huynh, Chem. Rev. 2018, 118, 9457.

[5] D. Martin, M. Melaimi, M. Soleilhavoup, G. Bertrand, Organometallics 2011, 30, 5304.

[6] a) Q. Liang, D. Song, Chem. Soc. Rev. 2020, 49, 1209; b) E. Peris, Chem. Rev. 2018, 118, 9928; c) Q. Zao, G. Meng, M. Szostak, S. P. Nolan, Chem. Rev. 2020, 120, 1981.

[7] a) J. F. Capon, S. E. Hassnaoui, F. Gloaguen, P. Schollhammer, J. Talarmin, Organometallics 2005, 24, 2020; b) J. W. Tye, J. Lee, H.-W. Wang, R. Mejia-Rodriguez, J. H. Reibenspies, M. B. Hall, M. Y. Darensbourg, Inorg. Chem. 2005, 44, 5550; c) D. Morvan, J. F. Capon, F. Gloaguen, A. Le Goff, M. Marchivie, F. Michaud, P. Schollhammer, J. Talarmin, J. J. Yaouanc, R. Pichon, N. Kervarec, Organometallics 2007, 26, 2042; d) L. Duan, M. Wang, P. Li, Y. Na, N. Wang, L. Sun, Dalton Trans. 2007, 1277; e) M. L. Singleton, R. M. Jenkins, C. L. Klemashevich, M. Y. Darensbourg, C. R. Chimie 2008, 11, 861; f) C. M. Thomas, T. Liu, M. Y. Darensbourg, Inorg. Chem. 2008, 47, 7009; g) D. Morvan, J.-F. Capon, F. Gloaguen, F. Y. Pétillon, P. Schollhammer, J. Talarmin, J. J. Yaouanc, F. Michaud, N. Kervarec, J. Organomet. Chem. 2009, 694, 2801; h) L. C. Song, X. Luo, Y. Z. Wang, B. Gai, Q.-M. Hu, J. Organomet. Chem. 2009, 694, 103; i) R. D. Bethel, D. J. Crouthers, C. H. Hsieh, J. A. Denny, M. B. Hall, M. Y. Darensbourg, Inorg. Chem. 2015, 54, 3523; j) D. Chouffai, G. Zampella, J. F. Capon, L. De Gioia, A. Le Goff, F. Y. Pétillon, P. Schollhammer, J. Talarmin, Organometallics 2012, 31, 1082; k) B. Borthakur, A. K. Phukan, Dalton Trans 2019, 48, 11298 ; 1) B. Borthakur, A. Vargas, A. K. Phukan, Eur. J. Inorg. Chem. 2019, 17, 2295; m) L.-C. Song, J.-S. Chen, G.-J. Jia, Y.-Z. Wang, Z.-L. Tan, Y.-X. Wang, Organometallics 2019, 38, 1567; n ) K. Riener, S. Haslinger, A. Raba, M. P. Hörgel, M. Cokoja, W.A. Herrmann, F. E. Kühn, Chem. Rev. 2014, $114,5215$.

[8] a) G. Guisado-Barrios, J. Bouffard, B. Donnadieu, G. Bertrand, Angew. Chem. Int. Ed. 2010, 49, 4759; b) P. Mathew, A. Neels, M. Albrecht, J. Am. Chem. Soc. 2008, 130, 13534.

[9] A. Winter, L. Zsolnai, G. Huttner, Z. Naturforsch. 1982, 87 b, 1430

[10] S. Sanghi, E. Willett, C. Versek, M. Tuominen, E. B. Coughlin, RSC Advances 2012, 2, 848 .

[11] F. Arrigoni, S. Mohamed Bouh, C. Elleouet, F. Y. Pétillon, P. Schollhammer, L. De Gioia, G. Zampella, Chem. Eur. J. 2018, 24, 15036.

[12] L. J. Farrugia, J. Appl. Crystallogr. 1999, 32, 837.

\section{License and Terms}

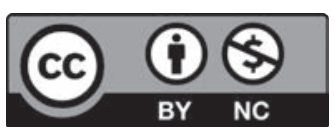

This is an Open Access article under the terms of the Creative Commons Attribution License CC BY_NC 4.0. The material may not be used for commercial purposes.

The license is subject to the CHIMIA terms and conditions: (http:// chimia.ch/component/sppagebuilder/?view=page \&id=12).

The definitive version of this article is the electronic one that can be found at doi:10.2533/chimia.2020.499. 